Vol. 3, No. 2, 2021

https://doi.org/10.23939/jtbp2021.02.032

Vadym Orel, Bohdan Pitsyshyn, Tetiana Konyk

\title{
HYDRODYNAMICAL INSTABILITY OF NEWTONIAN FLOW BEFORE AN AXISYMMETRIC SUDDEN CONTRACTION
}

\author{
Department of Hydraulic and Water Engineering, \\ Lviv Polytechnic National University \\ vadym.i.orel@lpnu.ua
}

(C) Orel V., Pitsyshyn B., Konyk T., 2021

The sizes of the vortex region before the axisymmetric sudden contraction of the circular pipe at the Newtonian flow have been investigated. Area ratios 0.250 and 0.500 were considered. The sizes of the vortex region have the extreme dependence with a maximum at the transition of the laminar flow into a turbulent flow one. When the Reynolds number at the laminar flow increase, these sizes also increase, and they decrease at the turbulent flow. In both cases, the sizes of the vortex region are proportional to the Reynolds number. A transition region between laminar flow and turbulent flow lies in the range of the Reynolds number from 3000 to 5300 and 750-1300, determined by the diameter of a bigger pipe of sudden expansion and a step height correspondingly.

Keywords: sudden contraction, pipe diameter, step height, vortex region, vortex length, vortex height, area ratio, Reynolds number.

\section{Introduction}

Dissipative zones of the flow separation from the walls of a channel cause maximum power losses (Arsirij, 2003). Theoretical analysis of the flows with separation in general is impossible. Until now, only one possible way to determine the hydraulic characteristics is an experiment (Tananaev, 1979).

Let us consider the axisymmetric sudden contraction of the circular pipe as one of the easiest local hydraulic resistance, where the separation of the transit stream from the pipe walls occurs (Fig. 1). Pressure losses are caused, first, by flow friction at the pipe inlet of the diameter $\mathrm{D}_{2}$ and, second, by appearing the vortex regions with the sizes of $\left(L_{1} ; H_{1}\right)$ and $\left(L_{2} ; H_{2}\right)$ (Bajbakov, Bashta, Kirillovskij, Nekrasov \& Rudnev, 1982). Sudden contraction belongs to such local hydraulic resistance, in which power losses due to occurring ring vortices are the most significant among minor pressure head losses (Moretskiy, Zholobov \& Varybok, 2017).

The vortex region before the sudden contraction occurs due to the presence of this local hydraulic resistance (Palacios-Sanchez, Noguchi-Machuca, Franco \& Morales, 2010; Bullen, Cheeseman \& Hussain, 1996), when the fluid flow at a wall slows down with further acceleration of its core part (Bullen et al., 1996). Under these conditions, a so-called hydrodynamic final domain of the length $\mathrm{L}_{1}$ occurs, where fluid flow destabilization with the disturbance of the structure of the uniform motion in the pipe of the diameter $\mathrm{D}_{1}$ (Kvitkovskij, 1986).

According to experimental data for the turbulent flow, the pressure drop of the part of a flow which is narrowed to the cross-section of the vena contracta $\mathrm{C}-\mathrm{C}$ (Fig. 1) is relatively small due to decreasing pulsations of velocities (Chugaev, 1982). Therefore, it is shown (Tananaev, 1979), that pressure drops on the sudden contraction occur mostly on the region of flow extension after the $\mathrm{C}-\mathrm{C}$ cross-section.

Let us pay attention to the sizes of the vortex region before axisymmetric sudden contraction at the Newtonian fluid flow. 


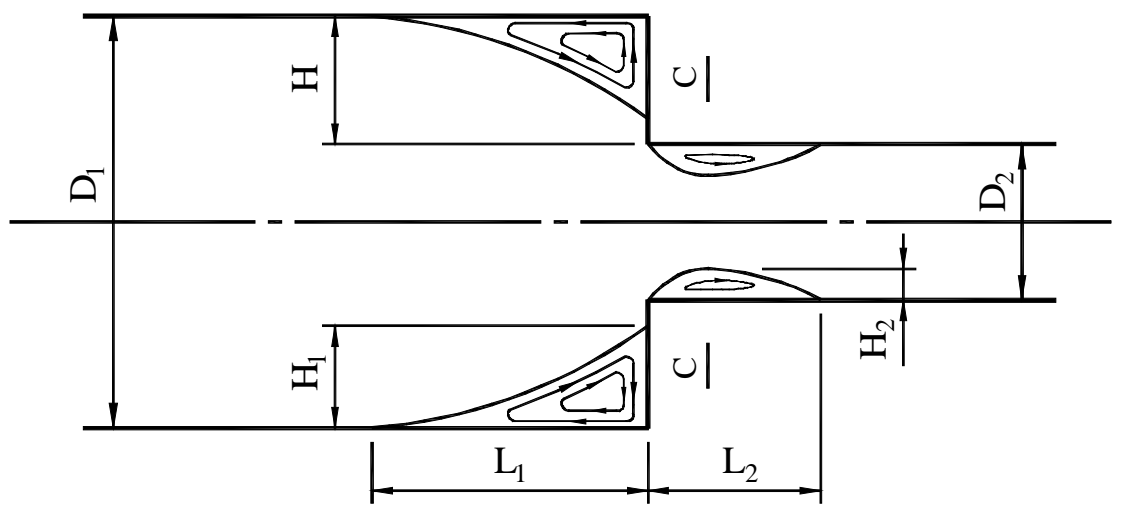

Fig. 1. Sizes of vortex regions before and after axisymmetric sudden contraction

According to kinematic characteristics of the flow at the turbulent flow through the sudden contraction of different shape (circular, rectangular, segmented), a formula was obtained (Kvitkovskij, 1986):

$$
\frac{L_{1}}{D_{1}}=a \cdot R e_{D 1}^{k}
$$

where $\mathrm{Re}_{\mathrm{D} 1}$ is the Reynolds number determined by a pipe diameter $D_{1} ; a$ is the empirical coefficient; $\mathrm{k}$ is the exponent.

For rectangular and square channels (Samohvalov, 1989):

$$
\frac{L_{1}}{b}=K_{L} \cdot \operatorname{Re} \cdot \frac{\omega_{1}}{\omega_{2}},
$$

where $b$ is the width of a channel; $\mathrm{K}_{\mathrm{L}}$ is the coefficient of the final domain depending on the type of transition zone and rheological of the fluid; $\omega_{1}, \omega_{2}$ are the areas of cross-section of the channel before and after changing its shape.

Experiments show the independence of vortex length $\mathrm{L}_{1}$ from Reynolds number $\mathrm{Re}$ and contraction ratio $\mathrm{D}_{2} / \mathrm{D}_{1}$ at $R e \leq 0.1$ and $\mathrm{D}_{2} / \mathrm{D}_{1} \leq 0.25$ (Boger, Hur \& Binnington, 1986); under these conditions $\mathrm{L}_{1} / \mathrm{D}_{1}=0.18$. Then $\mathrm{L}_{1}$ at $\mathrm{D}_{2} / \mathrm{D}_{1}=0.124-0.144$ monotonically decreases, while $\operatorname{Re}$ increases to $\operatorname{Re} \leq 90$ (Boger et al., 1986). In this case at $\mathrm{Re}=1-90$

$$
\frac{L_{1}}{D_{1}} \approx 0.155-0.023 \cdot \ln \operatorname{Re} .
$$

Let us consider the results of numerical modelling. At the laminar flow, the vortex length $\mathrm{L}_{1}$ decreases at the increase in the Reynolds number in a range $\mathrm{Re}_{\mathrm{D} 2}=1-50$ and increases at the decrease in the contraction ratio $D_{2} / D_{1}=0.25-0.8$ (Borzenko, Ryltseva, Frolov \& Shrager, 2017). At $D_{2} / D_{1}=0.534$, the vortex length $\mathrm{L}_{1}$ does not depend on the Reynolds number within the range $\mathrm{Re}_{\mathrm{D} 1}=23-196$, and then increases up to $\mathrm{Re}_{\mathrm{D} 1}=968$, then again does not depend on $\mathrm{Re}_{\mathrm{D} 1}$ up to 1200 . The vortex height change $\mathrm{H}_{1}$ is similar to changing the vortex length $\mathrm{L}_{1}$, and has its minimum at about $\operatorname{Re}_{\mathrm{D} 1}=200$ (Krhan \& Giorgini, 2016).

The transition region between the laminar flow and turbulent flow lies within the limits $\operatorname{Re}_{\mathrm{Dh}}$ from 3000 to 5000 , where $D_{h}$ is a hydraulic diameter (Reynaud, Debray, Franc \& Maitre, 2005).

At the turbulent flow, the length $\mathrm{L}_{1}$ and height $\mathrm{H}_{1}$ decrease while the Reynolds number is increasing within the range $\mathrm{Re}_{\mathrm{D} 1}=4900-24600$ at $\mathrm{D}_{2} / \mathrm{D}_{1}=0.440$ (Wendt, 2015).

The considered results were obtained at different relative diameters of the pipe inlet $D_{2} / D_{1}$, which complicates their comparison. 


\section{The purpose of the study}

The purpose of study is to reveal the regularity of the changes of sizes of the vortex region before the sudden contraction at the equal relative diameters of the inlet and the motion of the Newtonian fluid.

\section{Materials and methods}

The determination of the sizes of the ring vortex region before the sudden contraction was carried out according to the data given in Table 1 . In this case, a forward directed step conforms to the twodimensional case of sudden contraction (Ando \& Shakouchi, 2004). The area ratio $\mathrm{m} \geq 0.250$ were considered, since the measures directed to the decrease in power losses on the sudden contraction of the circular pipe should be effective at these particular values of the area ratios $m$ (Orel, 2013). It means that they should be implemented at the design stage.

Table 1

Investigated sudden contractions

\begin{tabular}{|c|c|c|c|c|c|c|c|c|}
\hline \multirow{2}{*}{ No } & \multirow{2}{*}{$\begin{array}{l}\text { Working } \\
\text { fluid }\end{array}$} & \multicolumn{2}{|c|}{$\begin{array}{l}\text { Pipe diameters, } \\
\mathrm{mm}\end{array}$} & \multirow{2}{*}{$\begin{array}{l}\text { Contraction } \\
\text { ratio } \\
\mathrm{D}_{2} / \mathrm{D}_{1}\end{array}$} & \multirow{2}{*}{$\begin{array}{c}\text { Area } \\
\text { ratio } \\
\mathrm{m}\end{array}$} & \multicolumn{2}{|c|}{ Step height } & \multirow{2}{*}{ Literature source used } \\
\hline & & $\mathrm{D}_{1}$ & $\mathrm{D}_{2}$ & & & $\begin{array}{l}\text { absolute } \\
\mathrm{H}, \mathrm{mm}\end{array}$ & $\begin{array}{l}\text { relative } \\
\mathrm{H} / \mathrm{D}_{1}\end{array}$ & \\
\hline 1 & $\begin{array}{c}\text { water } \\
+ \\
\text { glycerine }\end{array}$ & 23.9 & 12.15 & 0.508 & 0.258 & 5.875 & 0.246 & $\begin{array}{l}\text { (Palacios-Sanchez, 2011; } \\
\text { Palacios-Sanchez et al., 2010) }\end{array}$ \\
\hline 2 & oil & 200 & 100 & 0.500 & 0.250 & 50.0 & 0.250 & (Popov, 2000) \\
\hline 3 & \multirow{3}{*}{ water } & \multirow{3}{*}{60} & 30 & 0.500 & 0.250 & 15.0 & 0.250 & \multirow{3}{*}{ (Ando \& Shakouchi, 2004) } \\
\hline 4 & & & 34 & 0.567 & 0.321 & 13.0 & 0.217 & \\
\hline 5 & & & 44 & 0.733 & 0.538 & 8.0 & 0.133 & \\
\hline 6 & air & - & - & - & 0.500 & 20.0 & - & $\begin{array}{l}\text { (Barbosa-Saldana, Morales- } \\
\text { Contreras, Jimenez-Bernal, } \\
\text { Gutierrez-Torres \& } \\
\text { Moreno-Pacheco, 2013) }\end{array}$ \\
\hline 7 & water & 19.1 & 10.2 & 0.534 & 0.285 & 4.45 & 0.233 & (Krhan \& Giorgini, 2016) \\
\hline
\end{tabular}

Area ratio is calculated as:

$$
m=\frac{\Omega_{2}}{\Omega_{1}},
$$

where $\Omega_{1}, \Omega_{2}$ are areas of cross-sections before and after the step correspondingly:

- $\quad$ for the sudden contraction

$$
\Omega_{i}=\frac{\pi D_{i}^{2}}{4},
$$

where $D_{i}$ is the pipe diameter before or after section of contraction. Then formula (4) can be written as follows:

$$
m=\frac{D_{2}^{2}}{D_{1}^{2}}
$$


- for a forward facing step

$$
\begin{gathered}
\Omega_{1}=H_{c} \times b ; \\
\Omega_{2}=\left(H_{c}-H\right) \times b,
\end{gathered}
$$

where $\mathrm{H}_{\mathrm{c}}$ is the height of the channel before a forward facing step; $\mathrm{H}$ is the step height. Then formula (4) can be rewritten as:

$$
m=1-\frac{H}{H_{c}} .
$$

The step height for sudden contraction is:

$$
H=\frac{D_{1}-D_{2}}{2} .
$$

\section{Results and discussion}

A data (Palacios-Sanchez, 2011; Palacios-Sanchez et al., 2010) analysis was conducted in (Orel, 2012). At the area ratio $m=0.250$ the existence of laminar flow and turbulent flow is evident (Fig. 2), and the critical Reynolds number should be in the range $\mathrm{Re}_{\mathrm{D} 1 \text {,crit }}=3000-5300$ (Fig. 2a), which matches values (Reynaud et al., 2005) and $\mathrm{Re}_{\mathrm{H}, \mathrm{crit}}=750-1300$ (Fig. 2b), where $\mathrm{Re}_{\mathrm{H}}$ is the Reynolds number determined by the step height $\mathrm{H}$.
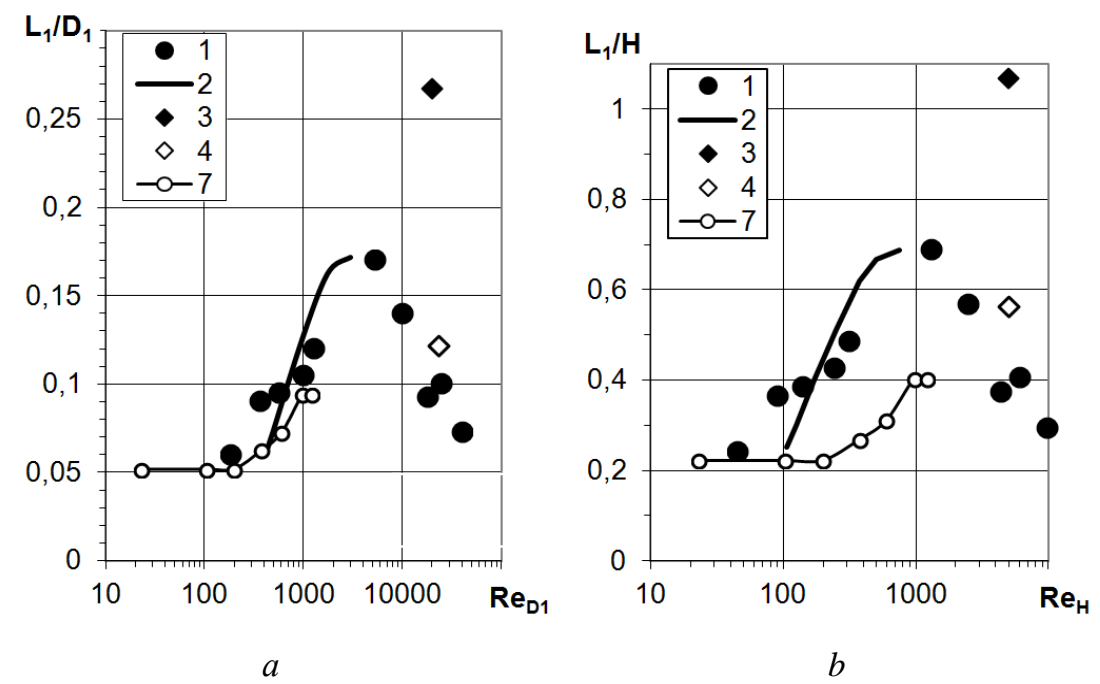

Fig. 2. Length of the vortex region before an axisymmetric sudden contraction (notations match those in the Table 1)

While the Reynolds number is increasing, the point of separation of the fluid flow before the sudden contraction moves upstream from the section of changing the diameter at the laminar flow, that shows the increase in $\mathrm{L}_{1}$; at the turbulent flow it moves downstream, showing the decrease in vortex length $\mathrm{L}_{1}$. At the laminar flow, it conforms to numerical modelling data (Krhan \& Giorgini, 2016) at $\mathrm{m}=0.285$. At the both flow regimes, the vortex length $\mathrm{L}_{1}$ change is proportional to the change of the Reynolds number.

However, at the turbulent flow, the change of $\mathrm{L}_{1}$ is more responsive to the increase in criterion Re, than at the laminar flow one. The same situation is observed at the flow of the Newtonian fluid through the sudden contraction (Fig. 3). It is described by the dependence $x_{R} / H=f\left(\operatorname{Re}_{d}\right)(B a c k$ \& Roschke, 1972), where $\mathrm{x}_{\mathrm{R}}$ is the reattachment length after the sudden expansion; $\mathrm{Re}_{\mathrm{d}}$ is the Reynolds number determined by 
the pipe diameter d. Described dependences can be approximated by formula (1) with the exponent $\mathrm{k}$ having negative and positive values for the appropriate flow regimes.

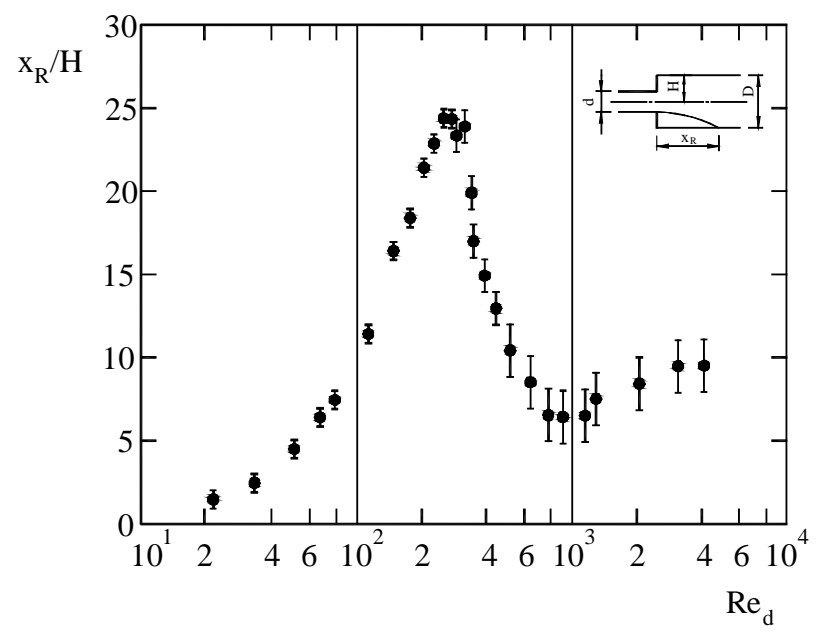

Fig. 3. Reattachment length after the axisymmetric sudden expansion

So, the vortex length $\mathrm{L}_{1}$ before the sudden contraction at the area ratio $\mathrm{m}=0.250$ has the extreme dependence with maximum at the transition of the laminar flow to the turbulent flow one. Therefore, at the laminar flow, the value of the Reynolds number increasing, the length increases and, at the turbulent flow, it decreases.

The tendency to changing the vortex height $\mathrm{H}_{1}$ of the vortex region before sudden contraction at the area ratio of $m=0.250$ is similar to changing the vortex length $L_{1}$ (Fig. 4). However, at bigger area ratio $\mathrm{m}=0.500$ compared with $\mathrm{m}=0.250$, the $\mathrm{H}_{1}$ is bigger for both flow regimes. Moreover, the vortex height $\mathrm{H}_{1}$ is smaller than step height $\mathrm{H}$ (Fig. 1), which indicates partial flow separation before the cross-section of the diameter change on the sudden contraction.
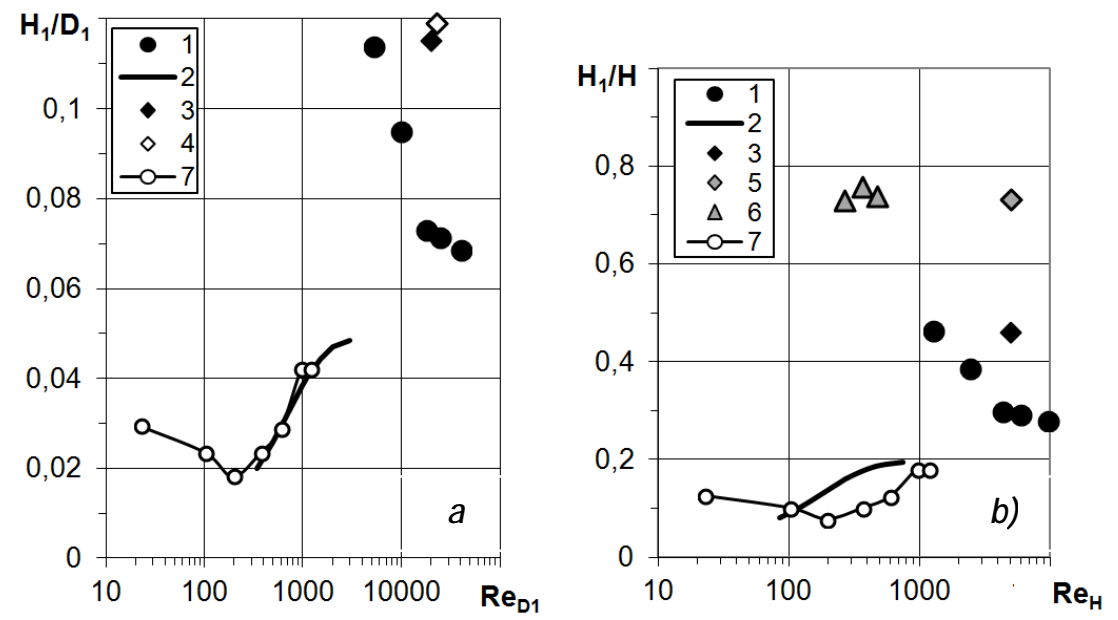

Fig. 4. Height of the vortex region before an axisymmetric sudden contraction (notations match those in the Table 1)

\section{Conclusions}

1. The vortex length and the vortex height before the sudden contraction have the extreme dependence with the maximum at the transition of the laminar flow to the turbulent flow one. With the increase in the Reynolds number at the laminar flow, the sizes of the vortex region increase, and at the turbulent flow they decrease. 
2. The Reynolds number determined by the pipe diameter $\mathrm{D}_{1}$ in the transition region between the laminar flow and the turbulent flow should be in the range from 3000 to 5300 . This statement matches data given in the scientific literature.

3. The vortex height before the sudden contraction of the circular pipe is smaller than the step height. Therefore, the partial fluid flow separation occurs before the cross-section of the diameter change on the sudden contraction.

\section{Prospects for further research}

It is necessary to investigate the sizes of the vortex region before the sudden contraction of the circular pipe at area ratios $m>0.250$, since for taking measures to reduce power losses, the processes of flow separation at the approach to the cross-section of the pipe diameter change should be known.

\section{References}

Ando, T. \& Shakouchi, T. (2004). Flow characteristics over forward facing step and through abrupt contraction pipe and drag reduction. Research Reports of the Faculty of Engineering, 29. Mie: Mie University. URL: www.eng.mie-u.ac.jp/research/activities/29/29_1.pdf.

Arsirij, V. A. (2003). Usovershenstvovanie gidro- i aerodinamiki oborudovaniya s cel'yu povysheniya effektivnosti. Proceedings of Odessa Polytechnic University, 2 (20), 1-5. [in Russian]

Back, L. H., \& Roschke, E. J. (1972). Shear-layer flow regimes and wave instabilities and reattachment lengths downstream of an abrupt circular channel expansion. Journal of Applied Mechanics, 39 (3), 677-681. DOI: https://doi.org/10.1115/1.3422772.

Bajbakov, O. V., Bashta, T. M., Kirillovskij, Yu. L., Nekrasov, B. B., \& Rudnev, S. S. (1982). Gidravlika, gidromashiny i gidroprivody: Uchebnik dlya mashinostroitel'nyh vuzov. Moskva: Mashinostroenie. [in Russian]

Barbosa-Saldana, J. G., Morales-Contreras, O. A., Jimenez-Bernal, J. A., Gutierrez-Torres, C. del C., \& MorenoPacheco, L. A. (2013). Numerical and experimental results for flow through a forward facing step channel. International Journal of Recent Research and Applied Studies, 15 (2) 177-189. URL: https://www.arpapress.com/ Volumes/Vol15Issue2/IJRRAS_15_2_06.pdf.

Boger, D. V., Hur, D. U., \& Binnington, R. J. (1986). Further observations of elastic effects in tubular entry flows, Journal of Non-Newtonian Fluid Mechanics, 20, 31-49, DOI: https://doi.org/10.1016/0377-0257(86)80014-3.

Borzenko, E. I., Ryltseva, K. E., Frolov, O. Yu., \& Shrager, G. R. (2017). Calculation of the local resistance coefficient of viscous incompressible fluid flow in a pipe with sudden contraction. Tomsk State University Journal of Mathematics and Mechanics. 48, 36-48. DOI: https://doi.org/10.17223/19988621/48/4.

Bullen, P. R., Cheeseman, D. J., \& Hussain, L. A. (1996). A study of Turbulent Flow in Pipe Contractions. Proceedings of the Institution of Mechanical Engineers, Part E: Journal of Process Mechanical Engineering; 210(3), 171-180. DOI: https://doi.org/10.1243/PIME_PROC_1996_210_312_02.

Chugaev, R. R. (1982). Gidravlika (Tekhnicheskaya mekhanika zhidkosti). Leningrad: Energoizdat, Leningradskoe otd-nie. [in Russian]

Krhan, A., \& Giorgini, F. (2016). Numerical investigations of laminar flow in a pipe with a sudden contraction of his cross-sectional area. Technical report. Linköping: Linköping University. URL: https://www.academia.edu/23612237/Numerical_investigations_of_laminar_flow_in_a_pipe_with_a_sudden_contra ction_of_his_cross-sectional_area.

Kvitkovskij Ju. V. (1986). O strukture i soderzhanii razdela gidrodinamiki 'Neravnomernoe napornoe dvizhenie zhidkosti'. In Metodika prepodavanija gidravliki napornyh techenij (pp.64-73). Leningrad: Leningradskij politehnicheskij institut. [in Russian]

Moretskiy, V. Y., Zholobov, V. V., \& Varybok, D. I. (2017). Influence of mutual placement of technological equipment onto hydraulic resistance. Science \& Technologies: Oil and Oil Products Pipeline Transportation, 1(28), 53-61. URL: https://elibrary.ru/item.asp?id=28777146. [in Russian]

Orel, V. I. (2012). Zalezhnist dovzhyny hidrodynamichnoi kintsevoi dilianky vid kryteriiu Reinoldsa pry raptovomu zvuzhenni potoku ridyny. III Mizhnarodna konferentsiia 'Naukovo-tekhnichne ta orhanizatsiino-ekonomichne spryiannia reformam u budivnytstvi i zhytlovo-komunalnomu hospodarstvi'. Makiivka, Ukraina. [in Ukrainian]

Orel, V. I. (2013). Investigation of the proportion of irreversible losses in total pressure losses at the sudden narrowing of pipe. Problems of Water supply, Sewerage and Hydraulics, 21, 181-190. [in Ukrainian] 
Palacios-Sanchez, F. M. (2011). Estudo Experimental do Escoamento de Fluido Newtoniano em Contração Abrupta Axissimétrica com a Técnica de Velocimetria por Imagem de Partículas. (Dissertação (Mestrado em Engenharia),, Universidade Tecnológica Federal do Paraná, Curitiba. URL: www.ppgem.ct.utfpr.edu.br/ dissertacoes/SANCHEZ,\%20Fredy\%20Palacios.pdf.

Palacios-Sanchez, F., Noguchi-Machuca, J. L., Franco, A. T., \& Morales, R. E. M. (2010). Experimental and numerical study of turbulent newtonian flow through an axisymmetric sudden contraction. Proceedings of ENCIT 2010. 13th Brazilian Congress of Thermal Sciences and Engineering. Uberlandia, MG, Brazil. URL: https://www.abcm.org.br/anais/encit/2010/PDF/ENC10-0572.pdf.

Popov, A. M. (2000). Razrabotka i realizaciya gidrodinamicheskogo metoda rascheta harakteristik drossel'nyh elementov gidroapparatury pri dokriticheskih chislah Rejnol'dsa (Doctor of philosophy dissertation). Moskovskij energeticheskij institut (tekhnicheskij universitet), Moskva. [in Russian]

Reynaud, S., Debray, F., Franc, J. P., \& Maitre, T. (2005). Hydrodynamics and heat transfer in twodimensional minichannels. International Journal of Heat and Mass Transfer, 48 (15), 3197-3211. DOI: https://doi.org/10.1016/j.ijheatmasstransfer.2005.02.020.

Samohvalov, A. S. (1989). Zakonomernosti techenij nen'yutonovskih zhidkostej na perekhodnyh uchastkah kanalov (Doctor of philosophy dissertation). Kyiv Civil Engineering Institute, Kyiv. [in Russian]

Tananaev, A. V. (1979). Techenie v kanalah MGD-ustrojstv. Moskva: Atomizdat. [in Russian]

Wendt, Elis M. S. (2015). Visualização de Escoamento Turbulento de Fluido Newtoniano em Contrações Abruptas com a Técnica PIV. Monografia. Curitiba: Universidade Tecnológica Federal do Paraná. URL: http://repositorio.roca.utfpr.edu.br/jspui/bitstream/1/10141/1/CT_DAMEC_2016_2_06.pdf.

В. І. Орел, Б. С. Піцишин, Т. 3. Коник

Національний університет “Львівська політехніка", кафедра гідротехніки та водної інженерії

\section{ГІДРОДИНАМІЧНА НЕСТАБІЛЬНІСТЬ ПОТОКУ НЬЮТОНІВСЬКОЇ РІДИНИ ПЕРЕД СИМЕТРИЧНИМ РАПТОВИМ ЗВУЖЕННЯМ ТРУБИ}

(C) Орел В. І., Піцчишин Б. С., Коник Т. 3., 2021

Заходи зі зменшення втрат енергії в системах трубопровідного транспорту необхідно впроваджувати вже на етапі проектування. Зокрема це стосується й місцевих гідравлічних опорів трубопроводів. Досліджено розміри вирового поясу перед симетричним раптовим звуженням круглої труби за течії ньютонівської рідини. Розглянуто ступені звуження потоку 0,250 та 0,500. Адже заходи, спрямовані на зменшення втрат енергії на раптовому звуженні круглої труби, мають бути ефективними за ступенів звуження потоку не менших ніж 0,250. Розміри вирового поясу мають екстремальну залежність з максимумом під час переходу ламінарного режиму руху рідини в турбулентний. Зі збільшенням значень критерію Рейнольдса за ламінарного режиму ці розміри зростають, а за турбулентного режиму - зменшуються. У першому випадку точка відриву потоку зміщується вверх за течією від площини зміни діаметрів, що узгоджується з даними чисельного моделювання, наведеними в літературі; у другому випадку - донизу за течією. В обох випадках розміри вирового поясу є пропорційними до критерію Рейнольдса. Описана поведінка $є$ аналогічною як для довжини зони повторного приєднання потоку ньютонівської рідини після раптового розширення труби. Перехідна зона між ламінарним і турбулентним режимами руху рідини є в межах від 3000 до 5300 та 750-1300 для критерію Рейнольдса, визначеного за діаметром більшої труби та уступом відповідно. Це узгоджується з наведеними в літературі даними. Висота вирового поясу перед раптовим звуженням круглої труби є меншою за висоту уступу. Відбувається неповний відрив потоку рідин перед перерізом зміни діаметрів.

Ключові слова: раптове звуження труби, діаметр труби, висота уступу, вировий пояс, довжина виру, висота виру, ступінь звуження потоку, критерій Рейнольдса. 